\title{
Efficacy of Selected Insecticides against Leaf Hopper [Amrasca biguttula biguttula (Ishida) of Okra [Abelmoschus esculentus (L.) Moench]
}

\author{
H. S. Randhawa and V. K. Pandey* \\ PAU Regional Research Station Gurdaspur, India \\ *Corresponding author
}

A B S T R A C T

\begin{tabular}{|c|}
\hline Keywords \\
\hline $\begin{array}{l}\text { Efficacy, Leaf } \\
\text { hopper, PAU, } \\
\text { Population, } \\
\text { Predators, } \\
\text { Revealed, Studies }\end{array}$ \\
\hline Article Info \\
\hline $\begin{array}{l}\text { Accepted: } \\
14 \text { May } 2020 \\
\text { Available Online: } \\
10 \text { June } 2020\end{array}$ \\
\hline
\end{tabular}

The field studies were conducted in the year 2017-18 to determine the efficacy of selected insecticides against leafhopper Amrasca biguttula biguttula (Ishida) of okra at PAU Regional Research Station Gurdaspur, Punjab (India). The studies revealed that all the treatments were found effective in reducing the population of leafhopper as compared to control. Thiamethoxam 25 WG @ $150 \mathrm{~g} / \mathrm{ha}$ was the most effective treatment indicating reduction in population of leafhopper and increase green fruit yield followed by Imidacloprid 17.8 SL and synthetic insecticide Malathion 50 EC @ 150 and $1400 \mathrm{ml}$ per hectare respectively. The highest cost benefit ratio (Rs. 1: 39.56) was achieved with Thiamethoxam and Imidacloprid (1: 38.76) followed it. The tested insecticides were also found safest to predators (spider and coccinelid) of okra insect-pests. The vegetable growers can make alternative spray of tested insecticides for management of okra leafhopper.

\section{Introduction}

India is the second largest producer of vegetables in the world next to China. Among vegetable, okra, Abelmoschus esculentus (L) Moench., is a nutritious food with many health benefits. It is rich in magnesium, calcium, folate, fibre, antioxidants, and vitamin $\mathrm{C}, \mathrm{K}_{1}$, and $\mathrm{A}$. Its medicinal value has also been reported in stabilizing blood sugar and shows anticancer properties (Habtamu et al., 2014). It is an important vegetable grown for its green tender fruits, which are used as a vegetable in a variety of ways. It can be fried and cooked with necessary ingredients.

All the plant stages are susceptible to insectpests and more than seventy two species of insect-pests have been recorded on okra crop (Srinivasa and Rajendran, 2003). These insect-pests cause 35-40\% crop yield losses and ultimately increase the level of damage 
up to $60-70 \%$ in optimal conditions (Salim, 1999). But leafhopper, Amrasca biguttula biguttula is considered to be the most destructive sucking pest of this crop (Dhandapani et al., 2003). It has become increasingly severe pest of vegetables, as well as some ornamental plants. Okra is the most suitable host for the survival and feeding of its nymph and, resulting in a loss of 50-63.41 $\%$ in yield (Sharma and Singh, 2002). Furthermore, leafhopper incidence caused a reduction of $49.80 \%$ and $45.10 \%$ in plant height and numbers of leaves, respectively (Rawat and Sadu, 1973).

The female adult are mainly oviposited their eggs inside the tissue of leaf blades, but may also be laid in leaf stalks or in soft twigs. The insect (nymphs and adults) suck the cell sap usually from the ventral surface of the leaves and while feeding inject toxic saliva into plant tissues. Infested leaves curl upward edges and develop brown dead spots with a yellow halo at the edge of the leaves; severely affected leaves may desiccate and fall off. This symptoms gradually affecting plant growth and cause reduction in fruit numbers and quality of produce. The insects also excrete honeydew from their body, and sooty mould fungus often develop on leaves, restricting the amount of light reaching the plant's photosynthetic surfaces and reducing the yield (Jayarao, et al., 2015). Among the various strategies adopted to combat the pest of okra, insecticides are the first line of defence.

Most of the insecticides used on vegetable crops are based on quite limited number of chemically different classes out of them the most important inorganic insecticides that are used against okra insect-pests belongs to synthetic pyrethroids and the indiscriminate use of these chemicals leads to adverse effects i.e. residues in vegetable produce, environmental contamination, resurgence, resistance and destruction of natural enemies which suggest the need to develop alternative management strategies (Dutta 2015). Therefore, an effort has been made in present investigation to evaluate the efficacy green chemistry selected insecticides against leafhopper in okra crop.

\section{Materials and Methods}

The field studies were conducted during kharif 2017-18 to determine the efficacy of selected insecticides against okra leafhopper, Amrasca biguttula biguttula. The experiment was laid out in randomized block design with four treatments (Imidacloprid, Thiomethoxam, Malathion \& untreated control) with four replication. The crop (variety Punjab 7) was sown in the last week of May both the years with spacing 45 X 15 $\mathrm{cm}$. The plot size was kept $30 \mathrm{~m}^{2}$ of each treatment and paths were maintained at 1.5 and 1.0 meter between replication and treatment plots as buffer, respectively. The crop was raised by following all agronomic recommendations of PAU for vegetable crops except plant protection measures. The tested insecticides were applied as foliar spray 40 days after sowing the crop and repeated with 15 days of intervals. The observations on the number of leafhoppers were made, a one day before followed by $3^{\text {rd }}, 7^{\text {th }}$ and $10^{\text {th }}$ days after spraying.

For recording observations, ten plants were randomly selected in each treatment. The leafhopper population was recorded from three leaves (top, middle and lower canopy) randomly selected of each plant (Latif et al., 2015). Population of leafhopper (nymphs and adults) were estimated by cutting randomly selected leaves and placed in a labelled polyethylene bags. Samples were put in freezer for about 30 minutes to immobilize leafhopper movement before counting numbers by using a magnifying lens $(2 \mathrm{x})(\mathrm{Al}-$ 
karboli and Al-Anbaki, 2014). The fruit yield at each picking from each net plot area was recorded and finally converted into quintal per hectare

\section{Pesticidal treatments and data analysis}

The present study was carried out to assess the relative bio-efficacy of newer selected molecules against okra leafhopper i.e. Imidacloprid $17.8 \quad$ SL $\quad$ (T1) and Thiamethoxam $25 \mathrm{WG}$ (T2) and standard check Malathion 50 EC (T3) insecticide @ $150 \mathrm{ml}, 150 \mathrm{~g}$ and $1400 \mathrm{ml}$ per hectare, respectively and untreated control (T4). The 250 litres of water per hectare was used with manually operated knapsack sprayer with flat fan nozzle for application of insecticides.

Increase in yield over control due to various insecticidal treatments

Increase in yield over control due to various treatments was worked out using following formula suggested by Khosla (1977).

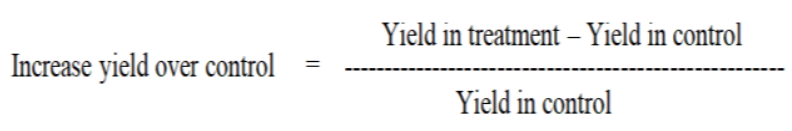

\section{Statistical analysis of data}

The data recorded during the course of investigation were subjected to statistical analysis by using analysis of variance technique with square root transformations (Gomez and Gomez 1984).

\section{Economics}

In order to know the economics of different treatments evaluated against insect pests of okra, Incremental Cost Benefit Ratio (ICBR) was worked out. For this purpose, total cost of insecticidal treatment per hectare was calculated for each treatment based on the prevailing market price. The increased yield over control was calculated by subtracting the yield obtained in control treatment from the yield obtained each insecticidal treatment. Then, the gross realization over control was worked out for each treatment based on the increased yield of green fruit ( $q / \mathrm{ha}$ ) over control. The net green fruit yield $(\mathrm{q} / \mathrm{ha})$ for each treatment was computed by deducting the cost of insecticidal treatment from the values of gross realization over control. The ICBR i.e., net green fruit in rupee (Rs.) per rupee cost of insecticidal treatment was calculated by dividing net green fruit with the cost of treatment.

\section{Results and Discussion}

\section{Insecticidal effect of leafhopper population with different sprays}

\section{After first spray}

The data for okra leafhopper population recorded prior and 3, 7 and 10 days after spray with different treatments are presented in table 1. The recorded data indicated that leafhopper population was uniformly distributed in all the experimental plots as it evident from the observations recorded before imposing of insecticidal spray. The results further revealed that there was significant $(\mathrm{P}<0.05)$ difference in live population of plant hopper, A. biguttula biguttula on okra plants sprayed with selected insecticides $(\mathrm{p}=0.05)$ at different post-treatment periods. The data showed that 3, 7 and 10 days after treatment the mean live population of leafhopper per leaf was $0.88,1.00 \& 1.77$ (av. 1.22) when sprayed with Thiomethoxam 25 WG @ 150 g/ha; $1.00,1.27 \& 2.00$ (av. 1.42), sprayed with Imidacloprid 17.8 SL @ $150 \mathrm{ml} / \mathrm{ha}$ and $5.44,2.70 \& 4.40$ (av. 3.78) when sprayed with Malathion@1400 ml/ha. In untreated control plots the live population of okra leaf hopper per leaf was 6.82, 9.95 and 10.15 (av. 
8.97). The comparative effect of new insecticides indicates that Thiomethoxam resulted higher reduction $(86.44 \%)$ on leaf hopper population on okra, followed by Imidacloprid (84.13\%) and Malathion (59.90 $\%)$. Therefore it is observed that the new insecticides (Thiamethoxam and Imidacloprid) proved to be more essential insecticides for controlling live population of okra leafhopper than standard insecticide (Malathion). The population (Table 1) of natural enemies prevailing in okra crop was very low. However, the population of predators (spiders and ladybird beetle) was observed during the study period. There was no significant effect of any of the insecticidal treatments on predators of okra insect-pests after 3, 7 and 10 days of application as the data are non-significant.

\section{After second spray}

The data (Table 1a) live leafhopper population recorded after 3,7 and 10 days after second insecticidal spray showed that population differed significantly $(\mathrm{P}=0.05)$ with different treatments. It is obvious from the data (Table 1a) that after 3, 7 and 10 days of treatment the live population of leafhopper per leaf was $1.36,1.21 \& 1.67$ (av. 1.41) on okra crop when sprayed with Thiamethoxam @ $150 \mathrm{~g} / \mathrm{ha} ; 1.70,1.36 \& 1.81$ (av. 1.59) with Imidacloprid (150 ml/ha); 4.50, 4.54 \& 5.14 (av. 4.73) with application of Malathion (1400 ml/ha) and 9.23, $9.38 \& 10.73$ (av. 9.78) in untreated control plots. The comparative effect of insecticides indicates (Table 1a) that the maximum reduction in leafhopper $(82.92 \%)$ was recorded with application of Thiomethoxam and it was followed by application of Imidacloprid $(81.49 \%)$ and Malathion (47.44 \%). The mean population of natural enemies (Insectpests' predator) i.e. spiders (0.11-0.14) and lady bird beetle $(0.03-0.07)$ per plant differed-non significantly with different insecticidal treatments. Therefore, it means the tested insecticides are safer to natural enemies.

\section{Average marketable fruit yield and cost benefit ratio}

The data (Table 2) on pooled (different pickings) marketable okra fruits yield per hectare during 2017-18 was maximum (94.74 q) harvested from the plots sprayed with Thiamethoxam. However, it was at par with application of Imidacloprid $(91.80 \mathrm{q})$ and significantly better than application of Malathion (82.35 q). While the average lowest marketable fruit yield was $(71.92 \mathrm{q} / \mathrm{ha})$ recorded in untreated control plots. The yield analysis of field experiment demonstrated the efficacy of new selected molecules in significantly increasing okra fruit yield as compared to standard insecticide (Malathion) and untreated control. The highest Cost: Benefit (Table 2) was achieved with application of Thiamethoxam $(150 \mathrm{~g} / \mathrm{ha})$ i. e. Rs. 1 : 39.56 and it was followed by Imidacloprid (150 ml/ha) Rs. 1 : 38.76. The least cost benefit ratio (Rs. 1 : 10.12) was obtained with synthetic insecticide (Malathion).

These findings are in accordance with the findings of Preetha et al., (2009) reported that imidacloprid was found effective against jassids and whiteflies, the other neonicotinoid, thiomethoxam also provided similar levels of protection as that of imidacloprid. Similarly, Begum and Patil (2016) reported that Imidacloprid 17.8 SL was the most effective treatment indicating reduction in population of leafhoppers and whitefly. Pawar et al., (2016) reported that three sprays of Imidacloprid significantly reduced the mean population of aphids, jassids and whiteflies of okra crop. Dabhi et al., (2014) reported that Imidacloprid and Dimethoate found to be effective against okra leafhopper $(81 \%)$. 
Table.1 Efficacy of selected insecticides against leafhopper (Amrasca biguttula biguttula) in okra

\begin{tabular}{|c|c|c|c|c|c|c|c|c|c|c|c|c|c|c|c|c|}
\hline \multirow{5}{*}{$\begin{array}{c}\text { Treatment } \\
\text { No. }\end{array}$} & \multicolumn{6}{|c|}{ Mean leafhopper population } & \\
\hline & \multirow{2}{*}{\multicolumn{6}{|c|}{$\begin{array}{l}\text { On leaves: lower, middle and upper canopy of } 10 \text { plants } \\
\text { DAYS AFTER SPRAY }\end{array}$}} & \multirow{2}{*}{\multicolumn{10}{|c|}{$\begin{array}{c}\text { Per Plant (Mean of ten plants) } \\
\text { DAYS AFTER SPRAY }\end{array}$}} \\
\hline & & & & & & & & & & & & & & & & \\
\hline & \multirow[t]{2}{*}{ BS } & \multirow[t]{2}{*}{3} & \multirow[t]{2}{*}{7} & \multirow[t]{2}{*}{10} & \multirow[t]{2}{*}{ Mean } & \multirow{2}{*}{$\begin{array}{l}\text { Reduction over } \\
\text { control }(\%)\end{array}$} & \multicolumn{5}{|c|}{ Spider } & \multicolumn{5}{|c|}{ Beetle } \\
\hline & & & & & & & BS & 3 & 7 & 10 & Mean & BS & 3 & 7 & 10 & Mean \\
\hline T1 & $\begin{array}{c}5.95 \\
(2.63)\end{array}$ & $\begin{array}{c}1.00 \\
(1.41)\end{array}$ & $\begin{array}{l}1.27 \\
(1.50)\end{array}$ & $\begin{array}{l}2.00 \\
(1.73)\end{array}$ & $\begin{array}{l}1.42 \\
(1.53)\end{array}$ & 84.13 & 0.10 & 0.13 & 0.24 & 0.30 & 0.22 & 0.27 & 0.33 & 0.35 & 0.30 & 0.33 \\
\hline $\mathbf{T 2}$ & $\begin{array}{c}5.64 \\
(2.58)\end{array}$ & $\begin{array}{c}0.88 \\
(1.37)\end{array}$ & $\begin{array}{c}1.00 \\
(1.41)\end{array}$ & $\begin{array}{l}1.77 \\
(1.66)\end{array}$ & $\begin{array}{l}1.22 \\
(1.09)\end{array}$ & 86.44 & 0.17 & 0.09 & 0.20 & 0.33 & 0.21 & 0.23 & 0.28 & 0.31 & 0.32 & 0.30 \\
\hline T3 & $\begin{array}{c}5.44 \\
(2.54)\end{array}$ & $\begin{array}{c}2.70 \\
(1.92)\end{array}$ & $\begin{array}{c}4.40 \\
(2.32)\end{array}$ & $\begin{array}{l}4.23 \\
(2.28)\end{array}$ & $\begin{array}{l}3.78 \\
(2.08)\end{array}$ & 57.90 & 0.12 & 0.10 & 0.15 & 0.40 & 0.22 & 0.20 & 0.30 & 0.29 & 0.40 & 0.33 \\
\hline T4 & $\begin{array}{c}5.57 \\
(2.56)\end{array}$ & $\begin{array}{c}6.82 \\
(2.79)\end{array}$ & $\begin{array}{l}9.95 \\
(3.30)\end{array}$ & $\begin{array}{l}10.15 \\
(3.33)\end{array}$ & $\begin{array}{l}8.97 \\
(2.89)\end{array}$ & - & 0.16 & 0.18 & 0.21 & 0.41 & 0.27 & 0.30 & 0.37 & 0.25 & 0.36 & 0.33 \\
\hline $\mathrm{CD}(\mathrm{p}=0.05)$ & NS & $(0.09)$ & $(0.21)$ & $(0.17)$ & $(0.34)$ & - & NS & NS & NS & NS & NS & NS & NS & NS & NS & NS \\
\hline
\end{tabular}

BS : before Spray ; Figures in the parentheses are square root transformations

Table.1a Efficacy of selected insecticides on leafhopper (Amrasca biguttula biguttula) in okra

\begin{tabular}{|c|c|c|c|c|c|c|c|c|c|c|c|c|c|c|c|c|}
\hline \multirow[t]{4}{*}{ Treatment No. } & \multicolumn{6}{|c|}{ Mean leaf hopper population } & \multirow{2}{*}{\multicolumn{10}{|c|}{$\begin{array}{c}\text { Mean population of natural enemies } \\
\text { Per Plant (Mean of ten plants) }\end{array}$}} \\
\hline & \multicolumn{6}{|c|}{ On leaves: lower, middle and upper canopy of 10 plants } & & & & & & & & & & \\
\hline & \multirow[t]{2}{*}{ BS } & \multirow[t]{2}{*}{3} & \multirow[t]{2}{*}{7} & \multirow{2}{*}{10} & \multirow{2}{*}{ Mean } & \multirow{2}{*}{$\begin{array}{l}\text { Reduction over } \\
\text { control }(\%)\end{array}$} & \multicolumn{5}{|c|}{ Spider } & \multicolumn{5}{|c|}{ Beetle } \\
\hline & & & & & & & BS & 3 & 7 & 10 & Mean & BS & 3 & 7 & 10 & Mean \\
\hline T1 & $\begin{array}{c}5.18 \\
(2.48)\end{array}$ & $\begin{array}{c}1.70 \\
(1.64)\end{array}$ & $\begin{array}{c}1.36 \\
(1.53)\end{array}$ & $\begin{array}{c}1.81 \\
(1.68)\end{array}$ & $\begin{array}{c}1.62 \\
(1.59)\end{array}$ & 81.49 & 0.03 & 0.14 & 0.15 & 0.10 & 0.13 & 0.09 & 0.17 & 0.03 & 0.06 & 0.05 \\
\hline $\mathbf{T 2}$ & $\begin{array}{c}4.57 \\
(2.36)\end{array}$ & $\begin{array}{c}1.36 \\
(1.54)\end{array}$ & $\begin{array}{c}1.21 \\
(1.49)\end{array}$ & $\begin{array}{c}1.67 \\
(1.63)\end{array}$ & $\begin{array}{c}1.41 \\
(1.58)\end{array}$ & 82.92 & 0.07 & 0.20 & 0.14 & 0.08 & 0.14 & 0.12 & 0.09 & 0.04 & 0.07 & 0.07 \\
\hline T3 & $\begin{array}{c}6.77 \\
(2.78)\end{array}$ & $\begin{array}{c}4.50 \\
(2.34)\end{array}$ & $\begin{array}{c}4.54 \\
(2.35)\end{array}$ & $\begin{array}{c}5.14 \\
(2.47)\end{array}$ & $\begin{array}{c}4.73 \\
(2.45)\end{array}$ & 47.44 & 0.10 & 0.13 & 0.10 & 0.13 & 0.12 & 0.07 & 0.03 & 0.04 & 0.02 & 0.03 \\
\hline T4 & $\begin{array}{c}8.65 \\
(3.10)\end{array}$ & $\begin{array}{c}9.23 \\
(3.19)\end{array}$ & $\begin{array}{c}9.38 \\
(3.22)\end{array}$ & $\begin{array}{l}10.73 \\
(3.42)\end{array}$ & $9.78(3.27)$ & - & 0.03 & 0.10 & 0.11 & 0.10 & 0.11 & 0.15 & 0.04 & 0.01 & 0.03 & 0.03 \\
\hline$C D(p=05)$ & $(0.04)$ & $(0.09)$ & $(0.11)$ & $(0.13)$ & (1.16) & - & NS & NS & NS & NS & NS & NS & NS & NS & NS & NS \\
\hline
\end{tabular}

BS : before Spray ; DAS : Days after Spray Figures in the parentheses are square root transformations 
Table.2 Insecticidal effect on marketable yield and cost benefit ratio Fruit yield

\begin{tabular}{|c|c|c|c|c|c|c|}
\hline Treatment No. & $\begin{array}{c}\text { Marketable } \\
\text { fruit yield } \\
\text { (Q/ha) }\end{array}$ & $\begin{array}{c}\text { Increase } \\
\text { over } \\
\text { control }\end{array}$ & $\begin{array}{c}\text { Income of } \\
\text { increased yield } \\
\text { (Rs./ha) }\end{array}$ & $\begin{array}{c}\text { Cost of } \\
\text { Treatment } \\
\text { (Rs./ha) }\end{array}$ & $\begin{array}{c}\text { Net Profit } \\
\text { (Rs./ha) }\end{array}$ & $\begin{array}{c}\text { Cost : } \\
\text { Benefit } \\
\text { (Rs.) }\end{array}$ \\
\hline T1 & $91.80(9.58)$ & 19.88 & 31808.00 & 800.00 & 31008.00 & $1: 38.76$ \\
\hline T2 & $94.74(9.73)$ & 22.82 & 36504.00 & 900.00 & 35604.00 & $1: 39.56$ \\
\hline T3 & $82.35(9.07)$ & 10.43 & 16680.00 & 1500.00 & 15180.00 & $1: 10.12$ \\
\hline T4 & $71.92(8.48)$ & - & - & - & - \\
\hline $\mathbf{C D}(\mathbf{p = 0 . 0 5})$ & $(0.25)$ & - & - & - & - \\
\hline
\end{tabular}

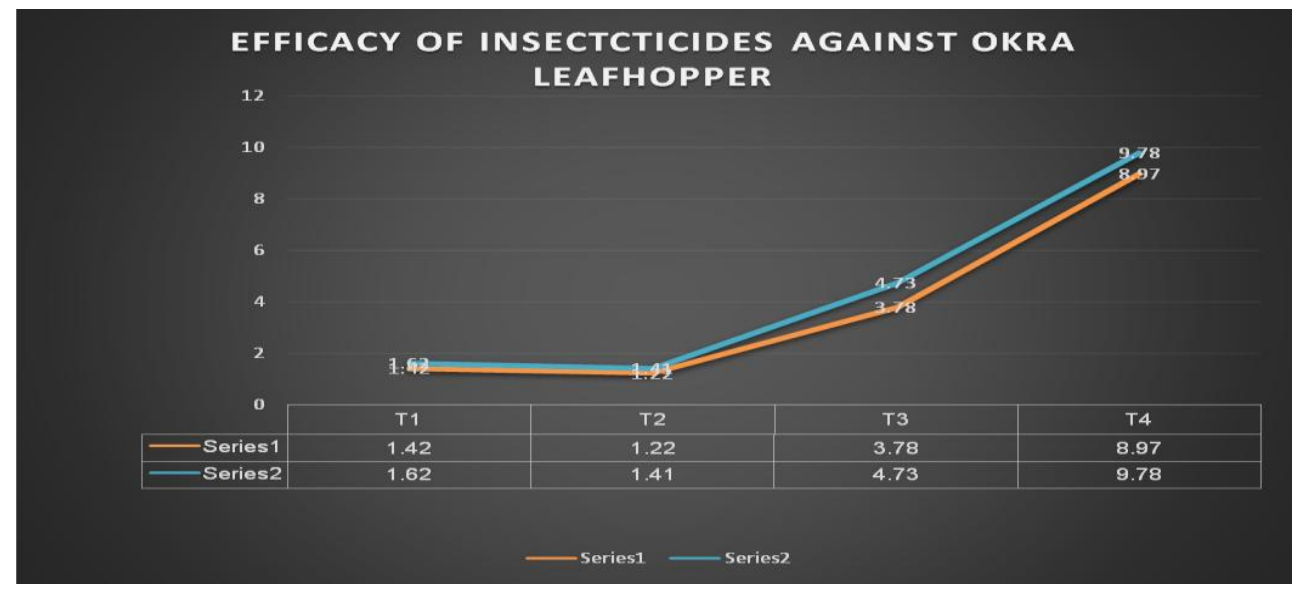

Fig.1 Efficacy of Insecticides against okra leafhopper

Similarly, Kumar and Kumar (2017) also reported that Imidacloprid 17.8 SL was most effective against whitefly (1.33/3 leaves) and jassid (1.26/3 leaves), followed by Thiamethoxam $25 \mathrm{WG}$.

The present study was concluded that the effect of Thiamethoxam and Imidacloprid @ $150 \mathrm{ml}$ and $150 \mathrm{~g}$ per hectare on suppuration of leaf hopper population of okra mainly proved best in reducing the population from the field. The tested insecticides resulted in more positive impact on the crop yield, other monetary parameters and resulted in highest amount of additional income as compared to other insecticide as well as over control. The tested insecticides found very safe towards the natural enemies (spiders and coccinellids) in okra crop and no phyto-toxic effects was observed on okra leaves, flowers and fruits. This study can be exploited for pest control in different fruits and vegetables. The Present findings of this research, it is suggested that vegetable growers can make alternative spray of Imidacloprid and Thiamethoxam against leafhopper in okra crop.

\section{Acknowledgement}

We are grateful to Director PAU Regional Research Station Gurdaspur for providing facilities for this research work.

\section{References}

Al-karboli, H. H. and AL-Anbaki, H. A. (2014). Efficacy of two sampling methods for monitoring, control and estimating seasonal abundance of onion thrips, Thrips tabaci Lindeman (Thripidae: Thysanoptera on onion in Iraq. Journal. of Agricultural Technology 10:243-251.

Begum Khaja Rumana and Patil S., (2016). Evaluation of newer molecules of insecticides against sucking pests complex 
infesting okra. Indian Journal of Applied Research 6 : 94 -97.

Dabhi, M.V. and Koshiya, D. J. (2014) Effect of abiotic factors on population dynamics of leafhopper, Amrasca biguttula biguttula (Ishida) in okra. Advance Research Journal of Crop Improvement 5(1):11-14.

Dutta, S. (2015) Biopesticides: an eco-friendly approach for pest control. World Journal of Pharmacy and Pharmaceutical Sciences 4: 250-265.

Dhandapani, N., Shelkar, U. R. and Muruga, M. (2003). Bio-intensive pest management (BIPM) in major vegetable crop: an Indian perspective. Food Agricultural Environment 2: 333-339.

Habtamu, F. G., Negussie, R., Gulelat, D. S. \& Ashagrie, Z., Woldegiorgis, F. B. (2014) Nutritional quality and health benefits of okra (Abelmoschus Esculentus): 14 (6) version 1.0 Type: Double Blind Peer Reviewed International Research Journal Publisher: Global Journals Inc. (USA) Online ISSN: 2249-4618 \& Print ISSN: 0975-5888

Latif, Z., Ahmed, S., Sohail, K., Khan, L. and Issfaq, M. (2015). Population density of jassids (Amrasca biguttula bigutula and thrips (Thrips tabci) on cotton crop and efficacy of some botanical insecticides against cotton jassid and thrips. Journal of Biodiversity and Environmental Sciences 7: 272-280.

Rawat, R. R. and Sadu, H. R. (1973). Estimation of losses in growth and yield of okra due to Empoasca devastans (Dist.) and Earias spp. Indian Journal of Entomology 35:252-254.

Gomez, K. A. and Gomez, A. A. (1984) Statistical procedures for Agricultural Research (2 ed.). John Wiley and Sons, New York, 680 p.

Jayarao, B., Abulkhader, S. B., Naik, L. K. and
Vinaykumar, M. M. (2015). Assessment of Biology and morphometric characteristics of different stages of leafhopper, Amrasca biguttula biguttula (Ishida) on okra. The Bioscan 10: 671-674.

Khosla R K (1977) Techniques for assessment of losses due to pests and diseases. Indian Journal of Agricultural Sciences 47: 171174.

Kumar, K. N. P. and Kumar, A. (2017) Efficacy of selected Insecticides against sucking insect pests [Amrasca biguttula biguttula (Ishida) and Bemisia tabaci (Gennadius)] of Okra [Abelmoschus esculentus (L.) Moench] International Journal of Current Microbiology and Applied Sciences 6 (8): 3256-3259

Pawar, S.A., Zanwar, P.R., Lokare, S.G., Dongarjal, R.P. and Sonkamble, M. M. (2016). Efficacy of newer insecticides against sucking pests of okra. Indian Journal of Entomology, 78(3): 257-259.

Preetha, G., Manoharan, T., Stanley, T. and Kuttalam, S. (2009. Evaluation of imidacloprid against okra jassid, Amrasca biguttula biguttula (Ishida) and whitefly, Bemisia tabaci (Gennadius). Indian Journal of Entomology 71(3) : 209-214.

Salim, M., (1999) Diversity: role in integrated pest management. Science, Technology and Development $18: 26-31$.

Sharma, A. and Singh, R. (2002). Oviposition preference of cotton leafhopper in relation to leaf-vein morphology. Journal of Applied Entomology 126: 538-544.

Srinivasa, R. and Rajendran, R. (2003). Joint action potential of neem with other plant extracts against the leafhopper Amrasca devastance (Distant) in okra. Pest Management and Economic Zoology 10: 131-136.

\section{How to cite this article:}

Randhawa. H. S. and Pandey. V. K. 2020. Efficacy of Selected Insecticides against Leaf Hopper [Amrasca biguttula biguttula (Ishida) of Okra [Abelmoschus esculentus (L.) Moench]. Int.J.Curr.Microbiol.App.Sci. 9(06): 281-287. doi: https://doi.org/10.20546/ijcmas.2020.906.036 